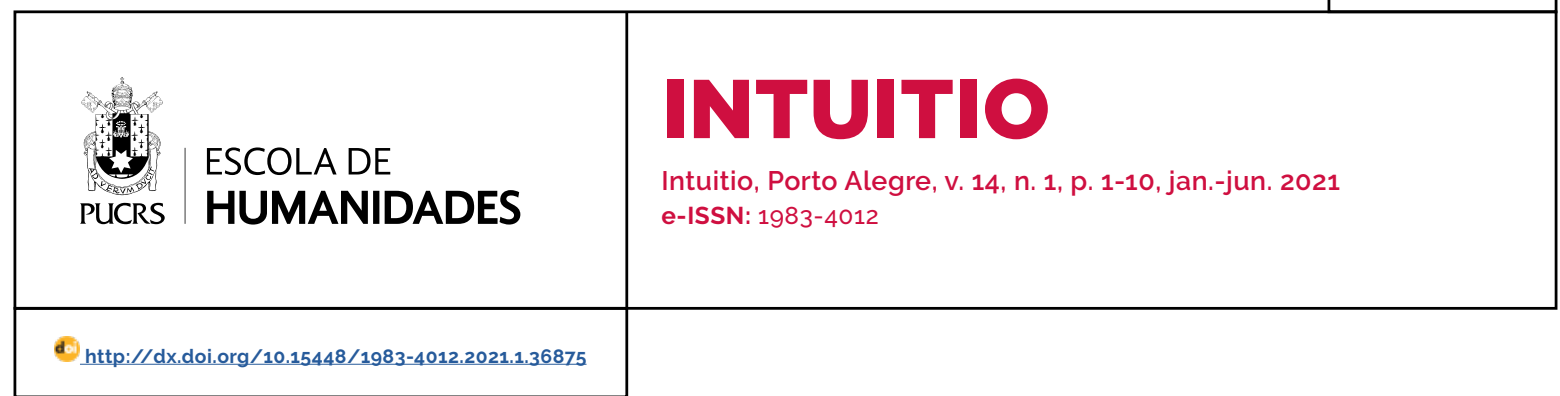

SEÇÃO: ARTIGO

\title{
A interioridade no livro $X$ das Confissões
}

The interiority in the book $X$ of Confessions

\section{Águeda Vieira \\ Martinelli ${ }^{1}$ \\ orcid.org/0000-0002-1935-1666 agueda.martinelli@acad.pucrs.br}

\section{Lilian Alencar da Silva ${ }^{2}$}

orcid.org/0000-0003-4501-2200 lialencar@hotmail.com

Recebido em: 16 jan. 2020 Aprovado em: 27 jul. 2021. Publicado em: 02 set. 2021.

\section{(c) (1)}

Artigo está licenciado sob forma de uma licença Creative Commons Atribuição 4.0 Internacional.
Resumo: O presente artigo analisa o livro/capitulo $X$ das Confissões de Agostinho, sob o viés da interioridade. Esse livro aborda de que maneira a memória se relaciona com a busca por Deus. Destaca-se que a possibilidade de procurar algo se deve a de alguma maneira estar guardado em nosso espírito tal memória. Porém, para encontrar Deus não basta a reminiscência. Isso porque a pessoa deve buscar Deus através da razão. A felicidade é algo que todos procuram, mesmo que muitas vezes as coisas do mundo pareçam ser a realização da felicidade. Assim, Agostinho analisa as concupiscências e revela que a verdadeira felicidade só se encontra em Deus. Além disso, devemos evitar os exageros, pois nos afastam de Deus. Agostinho observa que o ser humano é dividido entre a natureza e o infinito. Portanto, procuramos mostrar que a investigação de Agostinho oferece o relato de alguém numa constante busca por Deus. Também, sua análise revela uma pessoa em busca de autoconhecimento.

Palavras-chave: Memória. Espírito. Interioridade. Felicidade.

Abstract: The present paper analyzes the concept of interiority in the book/ chapter $X$ of Augustine's Confessions. This book discusses how memory relates to the pursuit of God. It also emphasizes that the possibility of looking for something is because we somehow have its memory in our minds. However, to find God, reminiscence is not enough. That is because one must look for God through reason. Happiness is something that everyone seeks, even though the things of the world often appear to be the fulfillment of happiness. So, Augustine analyzes the lusts and reveals that true happiness is found only in God. Besides it, he understands that we should avoid exaggerations because they only tear us away from God. Augustine observes that the human being is in-between nature and infinite. Thus, we aim to show that Augustine's analysis reports someone engaged in a constant search for God. Furthermore, his analysis shows a person who is also searching for self-knowledge.

Keywords: Memory. Spirit. Interiority. Happiness.

\section{Introdução}

No livro Confissões, Agostinho de Hipona recorda de eventos de sua vida e procura explorar as mudanças que ocorreram desde sua ruptura com o passado até sua transformação interior.

Percebe-se claramente o viés autobiográfico da obra, que está imersa em reflexões profundas a respeito de temas católico-cristãos e, também, filosóficos. Vale destacar que não é somente um relato de sua vida, mas as Confissões são apresentadas como uma longa oração feita por Agostinho a Deus utilizando a sua própria vida como "um exemplo concreto de como uma alma individual isolada pode se libertar desse estado e neoplatoni- 
camente ascender a uma unidade que supera o isolamento e atinge o repouso em Deus"3, como explica Mendelson. Para tal, "sua seleção de eventos é bastante deliberada e ele foca especialmente em sua imersão e libertação do que ele considera sua visão do mundo pré-reflexiva, materialista e senso comum"4, como explica Mendelson.

Portanto, trata-se de uma conversa dirigida a Deus de uma maneira muito intima e sincera e vem sendo chamada de "a primeira autobiografia introspectiva da história", mas "uma vez que concluímos nossa leitura do livro 9, a seção final narrativamente autobiográfica, nós temos ainda por vir uns 40\% da história de Agostinho"5 nas palavras de Fredriksen. Sendo que a memória é abordada no livro $X$, e é um tema que Agostinho tem imenso interesse e desenvolve também em outras obras.

No que refere a obra Confissões, o argumento do capítulo $X$ do texto defende que a memória tem como função não somente armazenar lembranças, mas que desempenha um trabalho no âmbito da cognição e da percepção. É através do "exercício de sua memória que o individuo - tempo-limite, imperfeito, mortal - é capaz de conhecer e de reconhecer a si mesmo e, mais es-

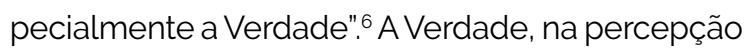
de Agostinho, se relaciona a Deus em um sentido teológico, o Deus do qual é falado na Bíblia.

Qual a dimensão que a memória tem para o pensamento agostiniano? Para ele, a memória é o caminho através do qual nós conseguimos encontrar Deus e, também, a nós mesmos. Agostinho chega à memória no livro $X$ das Confissões após analisar as possibilidades externas de encontrar Deus. Ele conclui que não há como encontrar Deus no mundo exterior, além das criações dele, como o próprio ser humano também é criatura Dele. Então ele se volta para o interior, isto é, para a alma. Nessa imersão Agostinho descobre a memória como o ponto mais semelhante à imagem de Deus que há no ser humano. Isso porque a memória, tal qual Deus, é não material.

Destacamos que nas Confissões Agostinho defende que o caminho para conhecer a si mesmo é através de Deus. No pensamento agostiniano, o conhecimento de si tem em Deus seu alicerce, mas a razão efetua a procura por Ele, de modo que não se trata de lembrar somente de Deus, mas procurá-lo de uma maneira consciente. Essa procura se revela um mergulho em si mesmo, porque afinal não há um lugar no mundo externo que possamos encontrar Deus, mas existe uma escada em nosso interior que nos leva até Ele e que em certo sentido é um autoconhecimento. No topo encontrar-se-á Deus.

A novidade que Agostinho traz no que refere à metafísica de Platão é precisamente a noção de interioridade na qual pode-se encontrar Deus, como explica Scherer. Como não temos acesso direto a Deus, a capacidade reflexiva do indivíduo pode levá-lo a experienciar Deus, mas ele se revela à pessoa, de modo que há um movimento duplo: o individuo o procura, mas Deus se revela para o individuo.

O pensamento de Agostinho foi influenciado, principalmente, pela leitura de Plotino das ideias platônicas, ou neoplatonismo. A noção de interioridade agostiniana é fortemente inspirada nestas leituras. Graças a tal influência, Agostinho consegue se libertar da visão maniqueísta que salientava uma perspectiva materialista da metafísica e "perceber, com surpresa, os numerosos pontos em comum entre a doutrina cristã e a platônica, de modo particular a centralidade da doutrina do logos em ambas",7 como explica Scherer. Essa ruptura foi determinante, porque a seita maniqueísta foi uma influência presente na vida de Agostinho por um longo periodo. Resumidamente, o maniqueísmo tinha como essencial uma cosmologia dualista, a qual entendia haver um mundo de luz, espiritual e considerado bom ou o bem e o mundo das trevas que é um mundo material ou o mal.

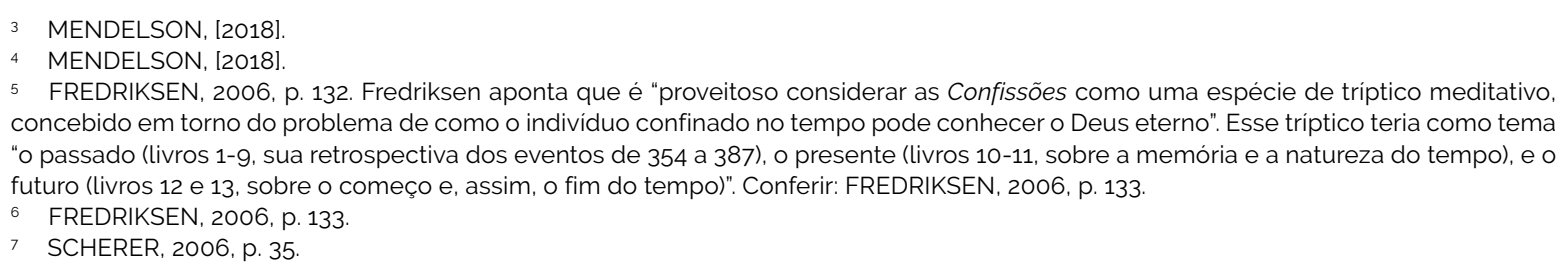


No presente artigo veremos que a análise realizada por Agostinho no livro $X$ das Confissões apresenta, graças ao viés da interioridade trazido pelo próprio autor, a oportunidade do autoconhecimento a partir desse confronto e da inquietação que é despertada.

Por isso, veremos qual o papel da memória nessa busca pelo eu verdadeiro e pelo sentido da vida. Para Agostinho, a memória é o ponto mais alto no que refere ao contato com Deus. Mas, no texto aqui analisado é ainda mais louvável o desenvolvimento alcançado quanto à interioridade. Pois, o ser humano não é somente um ser que possui uma mente e tem um mundo interior. Existe um mundo exterior e material no qual colhemos informações, retiramos experiências, sentimos. Em suma, um mundo que vivenciamos. Claro, a memória tem uma função importante para a vida prática e mental dos seres humanos, além de ser um elemento que faz parte da interioridade. Porém, existe essa tensão latente no ser humano: ele é interioridade, relação com o mundo externo e interno e relação com outras subjetividades. E Agostinho inclui essas nuances em sua investigação.

\section{Busca interior}

Ao ler as Confissões de Agostinho percebemos a importância que suas experiências têm como exemplo de vida. De um individuo isolado, isto é, que se percebe como um ser separado dos outros, e que muitas vezes não se vê conectado a seus semelhantes, Agostinho desdobra nessa obra sua evolução humana e espiritual sem ocultar as dificuldades que surgem. Porque é um caminho dificil confrontar e mudar a si mesmo. Além disso, propor a si mesmo descobrir o seu verdadeiro $\mathrm{Eu}$, ir até o limite de si para descobrir que não há limite e que tornar-se plenamente Eu é um trabalho constante.

Essa movimentação interna terá como uma das mais fundamentais descobertas o quanto estamos poluidos por "coisas" que assumimos como nossas, como nosso Eu, mas que não passam de utensilios. Podemos dar como exemplo as próprias linhas desenvolvidas na reflexão agostiniana: os exageros no que refere ao sexo, alimentação, bebida. Na atualidade é tão diferente do que Agostinho percebeu há mais de mil anos atrás? Pelo contrário, parece que o exagero qualifica a época em que vivemos.

Todavia, não se trata de um julgamento. O que realmente é relevante para nós neste artigo e mesmo em um nivel humano é a abertura para o questionamento sincero no indivíduo. Afinal, há tanta insatisfação para uma época que nos oferece tantas possibilidades materiais. De onde surge o vazio existencial se podemos ter tudo em tantas áreas? Isso é um paradoxo ou um curso inevitável? Alcançar o máximo de satisfação para descobrir, enfim, que há uma falta em nós que nenhuma materialidade preenche. Agostinho percebe através de suas Confissões que o vazio nele encontrou em Deus o caminho para a plenitude, onde um Eu verdadeiro pudesse ser alcançado.

No livro X Agostinho revela desde o começo o desejo de ser uma pessoa melhor, isto é, ele confessa implicitamente que não está completa a sua descida ao fundo de si mesmo. Ele deseja alcançar e praticar a verdade. Assim, sua confissão não deixa de ser também uma elaboração de si mesmo porque, como o próprio autor afirma, não há nada que ele possa esconder de Deus a respeito de si. Então, não é somente uma conversa com Deus, mas também consigo e com a humanidade que Agostinho empreende. E ele espera que aqueles que tomem conhecimento de sua confissão sejam caridosos e confiem no testemunho que ele dá de sua transformação interior. Quem sabe através do que ele diz possa inspirar as pessoas a não desistirem da busca pela verdade ou mesmo despertar para essa busca, que não deixa de ser em um primeiro momento a busca de uma verdade interna. Essa busca é uma depuração daquilo que apenas adotamos como se fosse nosso Eu verdadeiro. Trata-se de um processo de conscientização de si que Agostinho traz, pois ele está relatando o seu progresso não somente espiritual, mas humano enquanto busca por sentido e passa por todas as nuances psicológicas humanas possiveis.

É interessante a afirmação de Agostinho: "Existe, porém, algo no homem que nem sequer seu 
espírito conhece. Mas tu, Senhor, que o criaste, tudo conheces", 8 pois demonstra que há uma dimensão no ser humano que não se preenche. Essa dimensão é uma abertura que há em nós que nos motiva a perseguir sonhos, objetivos etc., e também gera tensão porque sentimos a falta e o vazio. Tal tensão é precisamente esta profundidade que há no ser humano, da qual em dados momentos tomamos consciência. É a tensão que abre o espaço da interioridade que há em nós e essa noção de interioridade é a experiência do individuo da profundeza humana.

Provavelmente a influência platônica e neoplatônica estão no cerne dessa visão que Agostinho aborda, pois Platão considerava que o ser humano está entre os extremos chamados de penia e poros (carência/indigência e abundância/plenitude). Assim, a estrutura do ser humano é definida pela carência que impele à busca e pelo eros (como é visto no Banquete de Platão) que é a tendência de alcançar/buscar um valor do qual se sente falta. Para mediar essas tendências há o logos que livra o indivíduo de tornar-se autocentrado por causa de seu eros e ao mesmo tempo manter a tensão permanente que é o que compele a busca teleológica da plenitude na forma do bem.

Agostinho passa a analisar o que conhece a respeito de seu próprio ser e mesmo o que sabe ignorar a respeito de si mesmo. Segue-se que Agostinho confessa "amar a Deus" sem dúvidas, pois, afinal, Ele tocou Agostinho - de tal modo que para ele foi inevitável estar em Seu caminho. Esse toque ou iluminação motivou-o a buscar a mudança. Algo diverso do que já vivenciou; algo que na visão do autor o aproxima de Deus, que é tido como o bem máximo. Mas, questiona Agostinho, o que ele ama em Deus? Não as percepções que vêm através dos sentidos, sejam as coisas dotadas de beleza, ou o esplendor da luz etc. Ama sim:

a luz, a voz, o odor, o alimento, o abraço do homem interior que habita em mim, onde para a minha alma brilha uma luz que nenhum espaço contém, onde ressoa uma voz que o tempo não destrói, de onde exala um perfume que o vento não dissipa, onde se saboreia uma comida que o apetite não diminui, onde se estabelece um contato que a saciedade não desfaz. Eis o que amo quando amo o meu Deus. ${ }^{9}$

Em outras palavras, ele indica que ama o eterno que há nelas, o que podemos entender como a ideia delas, ou seja, algo que não se perde porque não é corruptivel. Por isso, as ideias estariam mais próximas de Deus, o que aproxima Agostinho mais Dele.

Seguindo a análise, ele questiona a terra, os céus, o mar, os abismos e os seres vivos e percebe que eles não são Deus. Tudo que conseguiu compreender dessa investida foi que todas as coisas externas que somos capazes de perceber foram criadas por Deus. Contudo, esse empreendimento e as suas conclusões não devem ter o valor minimizado, pois se trata de uma constatação de que aquilo que percebemos através dos nossos sentidos são a primeira maneira de acolher o mundo e a vida. Ou seja, sentir é o primeiro degrau da descoberta de si mesmo, da descida ao interior de si e tomar consciência disso mostra ao indivíduo que ele está no mundo.

Em seguida, o filósofo questiona "quem sou eu"? Esse questionamento é de suma importância, porque aqui Agostinho afirma que é corpo e alma. Sem esse espanto consigo mesmo não é possivel empreender seriamente a procura pela verdade interna. Para Agostinho, a alma é superior porque é o divino no ser humano, ela é superior ao corpo, mas "o homem interior conheceu tais fatos graças ao homem exterior", 10 isto é, o corpo não pode ser excluido da equação.

Todavia, é preciso ultrapassar os sentidos para passo a passo alcançar Deus. Para muitas pessoas, esses passos não necessariamente levam a Deus, mas ao desenvolvimento humano promovido por essas reflexões profundas, por essa procura radical por si e pelo que é verdadeiramente a essência de um indivíduo. Isso é um processo que, apesar de doloroso, resulta em descobertas e mudanças irreversiveis. 


\section{A memória}

Erguendo-se da natureza e do mundo exterior, Agostinho considera subir até o Criador e chega dessa maneira à memória, onde são guardadas as imagens trazidas pela percepção além da atividade da mente. Todas as ideias que podem ser trazidas do mundo externo são armazenadas na memória: odores, sabores, coisas vistas. E a memória, essa incrivel capacidade que temos, faz parte da natureza humana. Apesar disso, não conseguimos apreender completamente quem somos, o que espanta Agostinho. Portanto, a memória se revela ser a "maneira que o homem é feito mais à semelhança de Deus; para o pensamento humano a memória humana é puramente não-material. $A$ memória de um objeto que não ocupa espaço. A vida mental, como Deus, é puramente espiritual"11 e, portanto, podemos entender porque a memória é uma noção tão essencial para Agostinho.

Além de armazenar as imagens do mundo externo, a memória tem a capacidade de armazenar as noções ou conhecimentos apreendidos. Mas, o mais interessante é que os conhecimentos não estão na memória apenas como imagens, mas são "as próprias realidades"12 que são carregadas. Ou seja, a memória não é somente o arquivo das imagens que possuimos, mas atua, além disso, nas nossas funções cognitivas, como no conhecimento a priori, explica Fredriksen. Por exemplo, o nome de algo como "existência" ou "liberdade": ao ouvir entendemos a palavra porque a temos na memória. Mas aquilo que significa liberdade e existência não foi percebido pelos sentidos. Para nosso entendimento, atualmente, esses tipos de objetos seriam considerados objetos mentais. Para Agostinho, são objetos percebidos com o espirito somente, não envolve a via do mundo exterior. Ele considera que foi depositada "na memória não suas imagens, mas as próprias substâncias", ${ }^{13}$ de modo que é dificil dizer como elas chegaram na memória, ou talvez estivessem sempre em nós e apenas aprendemos a reconhecê-las.
Em seguida, Agostinho aborda dois tipos de conhecimento, que explicam como existe em nosso espirito uma imagem sem que ela tenha sido percebida através dos sentidos e que seriam imagens em si mesmas. Em outras palavras, pode-se entender que é a essência da imagem porque ela não tem relação com o exterior, mas está no espirito.

O primeiro é quando algo está na memória de uma maneira confusa, mas é possivel organizar e acessar esse conhecimento sem dificuldade. Mas, se não são acessadas com frequência, perdem-se na memória. Desse modo, o pensamento deverá descobri-las na memória em busca do conhecimento ocultado para novamente reunir as informações e conhecê-las. Como destaca Agostinho:

Dessa operação deriva o verbo cogitar, estando cogo para cogito, como ago está para agito, facio para factito. No entanto, a palavra cogito tornou-se exclusiva do espírito, de modo que agora cogitar significa a ação de colher, mas somente no espírito, e não alhures. ${ }^{14}$

O segundo conhecimento é quando a memória contém também conhecimentos como os números, as relações, regras da matemática etc. O autor salienta que apesar de não serem conhecimentos apreendidos pelos sentidos, eles envolvem também uma dimensão da memória porque as palavras relacionadas a eles estão armazenadas na memória. Desse modo torna-se possivel saber do que se trata, porque mesmo que o nome de um número seja diferente nas mais diversas línguas, o número 1 é 1 em qualquer lugar, e as leis e regras da matemática também. Em outras palavras, esse tipo de conhecimento também se relaciona mais com as ideias do que com a materialidade e, portanto, é algo divino porque são conhecimentos a priori. Claro, noções como o circulo podem ter diferentes representações no mundo exterior, mas a ideia de circulo é sempre a mesma na mente.

Os sentimentos da alma, como refere Agostinho, também são guardados na memória, mas não do mesmo modo quando são experienciados. Como por exemplo, lembrar de uma alegria quando se

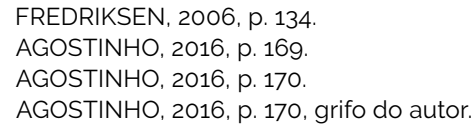


está triste ou outro sentimento. A lembrança não é simultânea como o sentimento que está sendo vivenciado no instante que a memória surge. Para Agostinho, a memória já é espírito. Espírito aqui parece estar mais ligado à alma, de maneira que a alma pode estar alegre, mas a memória traz uma lembrança triste e, por isso, existe essa ambiguidade. Isso acontece porque a memória efetua apenas a lembrança e não fica triste ou feliz com o que guarda. Nas palavras do autor

[...] por que será que, evocando com alegria uma tristeza passada, a alma contém a alegria, e a memória contém a tristeza? Se o espírito está alegre contendo em si alegria, por que a memória, que contém a tristeza, não está triste? Será que a memória não faz parte da alma? ${ }^{15}$

Sentimentos como alegria e tristeza têm uma ligação com a alma porque ocorrem nela, mas quando alcançam a memória não possuem o mesmo sabor de quando a alma sente. Ou seja, na alma os sentimentos também são como imagens dos sentimentos e, por isso, podemos nos recordar deles sem necessariamente sentir na alma os sentimentos. Afinal, são recordações dos sentimentos.

O desejo, a alegria, o medo e a tristeza são perturbações do espírito. Entretanto, mesmo essas afecções quando são recordadas não abalam necessariamente a pessoa, isto é, não significa que porque eu recordo uma alegria eu fique alegre e assim por diante, na visão de Agostinho. ${ }^{16}$ Isso porque tais perturbações estão guardadas na memória e se torna possivel acessá-las. Toda a análise de Agostinho tem como propósito mostrar que não somente os sons das palavras que se referem às imagens são impressos na memória através dos sentidos, - vindo do mundo exterior - mas também que as noções que nos chegam sem a via exterior são "confiadas à memória pelo espirito, depois de este havê-las experimentado e sentido, ou foram retidas pela memória sem que ninguém as tivesse confiado a ela", ${ }^{17}$ explica ele.

\section{A relação entre o esquecimento e a procura por Deus}

Agostinho começa a analisar o esquecimento, o que será importante para explicar por que se procura Deus. Dito isso, destaca-se que a preocupação de Agostinho nas Confissões não é provar a existência de Deus, mas sim, como e onde encontrar Deus. Como Scherer assere:

\begin{abstract}
Vale lembrar uma das teses agostinianas de que ninguém busca o desconhecido; no caso de Deus, ama-se o desconhecido no conhecido. Tendo o objeto de "apreensão" determinado, surge uma outra problemática: a razão humana, por si só, contém elementos suficientes para reconhecer a Deus, considerando que somente conseguimos identificar algo se já conhecemos "completamente"? A resposta é: não. O reconhecimento é assegurado por principios de ordem inteligivel, que estão presentes em nós, embora nem sempre tenhamos consciência deles. O responsável por explicitá-los e torná-los conscientes é o Mestre Interior, presente na base da memória. Os principios de ordem inteligivel também são conhecidos como verdades imutáveis e idênticas em todos. É por meio delas que nos orientamos é a elas que nos submetemos incondicionalmente, uma vez que são transcendentes, não dependendo praticamente do nosso entendimento. Procedendo assim, Agostinho afasta-se da teoria da reminiscência platônica pela qual a alma apenas recorda o que já viveu. Agora, passamos a conhecer por um ato consciente de interiorização em que a razão toma consciência da presença de Deus, a fonte da verdade - o Mestre Interior. ${ }^{18}$
\end{abstract}

E, assim, frisamos que a importância da interioridade para a análise e a questão do esquecimento pode agora ser trazida, para enfim entendermos a defesa agostiniana.

Agostinho expressa-se da seguinte maneira a respeito da memória e do esquecimento: quando lembramos do esquecimento, do que ele significa e não apenas da palavra, fazem-se presentes tanto a memória quanto o esquecimento. A memória se faz presente porque através dela é possivel lembrar o objeto, nesse caso o esquecimento. Portanto, trata-se de entender como é possivel que o esquecimento esteja presente na memória

15 AGOSTINHO, 2016, p. 171.

16 Podemos entender que o cérebro é uma parte física de algo imaterial que ocorre nele, a mente. Outra questão seria especular se a mente tem a ver com a alma, além de a própria alma ser uma questão em si mesma. Muitos cientistas e filósofos consideram que o ser humano é nada mais que algo material. Agostinho, por seu turno, parece considerar uma triade: corpo, alma e espírito.

17 AGOSTINHO, 2016, p. 172.

18 SCHERER, 2006, p. 38. 
se quando está presente impossibilita recordar, mas se nos lembramos do esquecimento ele é um conteúdo mental, ou seja, significa que o esquecimento está retido na memória.

Através de três hipóteses Agostinho procura explicar o esquecimento. Ele pondera: "deveria dizer que aquilo que recordo não está na minha memória, ou que o esquecimento está na minha memória com a finalidade de me fazer esquecer?" ou ainda "poderei dizer que a minha memória conserva a imagem do esquecimento, quando dele me lembro, e não o próprio esquecimento?"19. Porém, é preciso existir um objeto para que sua imagem seja impressa na memória. Entretanto, com a presença do esquecimento seria difícil gravar sua imagem na memória porque ele faz exatamente apagar o que está impresso lá.

Diante dessa dificuldade, Agostinho não consegue chegar a uma conclusão. Ele conclui, então, que não se trata de questionar o mundo lá fora, apesar de ser um degrau importante. mas de questionar a si mesmo. Além disso, ele percebe que a memória é o espírito e o espírito é ele próprio (Agostinho). E o seu ser interior é capaz de memória, que é uma capacidade que ele não consegue compreender plenamente. Essa reflexão leva Agostinho a entender que a interioridade é o caminho para Deus.

A interioridade é um caminho de autoconhecimento, um caminho que leva ao encontro com Deus, na visão agostiniana. Pode-se entender que Agostinho efetua uma renovação da "especulação filosófica sobre o homem, ao transformar o princípio filosófico-natural de Sócrates 'Conhece a ti mesmo, Senhor em um principio filosófico-religioso"20 no qual o conhecimento de si mesmo leva ao conhecimento de Deus e da verdade, além de trazer felicidade.

Portanto, onde encontrar Deus se, a princípio, Ele não está na memória? Encontramos Deus na nossa interioridade. Agora, como procurar Deus? Duas pistas seguidas pelo filósofo são a felicidade e a verdade. Tal questionamento é um passo decisivo para a investigação. O que motiva a busca por Deus é a esperança de encontrar a felicidade. A felicidade é algo que ao mesmo tempo desejamos, mas que todos os seres humanos podem experienciar.

\section{Onde encontrar Deus?}

À vista disso, Agostinho indaga de onde conhecemos a felicidade para desejá-la tanto? O que impulsiona a busca pela felicidade no ser humano é a memória da felicidade e isso significa que já fomos felizes. Portanto, a memória da felicidade é a memória de Deus em nós. Todos os homens desejam alcançar a felicidade, essa essência que reluz nela. Mas, como somos individuos, a busca pela felicidade é diferente para cada pessoa e se aproxima mais ou menos da verdadeira felicidade que para Agostinho é Deus.

Entretanto, a maneira como recordamos a felicidade não é a mesma que recordamos um lugar que conhecemos ou os números. Então, de onde surge esse desejo de felicidade? Quando ela foi vivenciada? Todas as pessoas têm experiências alegres, então parece que recordamos da felicidade como recordamos da alegria. Sentimos a alegria na alma e é possivel recordar uma alegria mesmo na tristeza, do mesmo modo que podemos desejar a felicidade estando infeliz. Sendo assim, "a busca da felicidade, portanto, é interior: ela tem o seu início na memória e exige um exercício de reflexão, tanto do sujeito que procura quanto do objeto procurado", ${ }^{21}$ explica Santos.

A verdadeira felicidade é alegrar-se em Deus por Ele, diz Agostinho. Todas as pessoas também desejam a verdade, e a "felicidade é o gozo da verdade, o que significa gozar de Ti, que és a verdade",22 apesar de que nem todos conseguem alcançar essa felicidade porque se dispersam.

Agostinho descobre que Deus está na memória, porque Agostinho se recorda Dele. Agora ele deseja saber onde está Deus na memória. Deduz que não há compartimentos na memória 
e Deus deve estar acima da memória. Por isso, conhecemos Deus em algum lugar anterior à vida humana, um lugar que não é lugar. Para Agostinho, a memória tem uma relevância muito grande, pois, conforme conclui Scherer:

[...] através dela que ocorre a identificação (nossa enquanto individuos, das coisas que nos rodeiam e de Deus), o aprendizado e o encontro com o Mestre Interior. Em outras palavras, a memória é o caminho pelo qual conhecemos a nós mesmos e através do qual chegamos ao conhecimento de Deus. ${ }^{23}$

\section{0 que impede de descobrir a felicidade?}

Após descobrir que buscamos a felicidade porque já fomos felizes e temos essa memória na nossa interioridade, o passo seguinte de Agostinho é analisar as concupiscências ou paixões, haja vista que elas são obstáculos à felicidade, que no seu auge é felicidade em Deus.

De que modo as paixões humanas podem desviar do caminho interior trilhado por alguém, seja para um conhecimento de si, seja para conhecimento de Deus? No capítulo 29 do livro X o autor se dirige a Deus afirmando que Ele nos ordena a continência, mesmo que isso seja um dom Dele concedido ao ser humano. A continência é determinante porque nos aproxima da unidade da qual nos afastamos, mas a força para resistir às paixões é uma força superior.

Assim, ele elabora o tema da concupiscência, sendo que esse termo vem da

tripartição de são João [que] classifica as concupiscências em: (1) concupiscência da carne; (2) concupiscência dos olhos; e (3) orgulho. Por sua vez, podemos dividir as concupiscências em concupiscência da alma (concupiscência da carne) e concupiscência do espirito (concupiscência dos olhos e orgulho). ${ }^{24}$

Dito isso, temos a concupiscência da carne, concupiscência dos olhos e da ambição do mundo.

A primeira está falando do concubinato e do matrimônio (da sexualidade) e o próprio filósofo confessa que esse ponto não é mais fácil para ele, mesmo ele tendo se convertido e procurando o caminho da correção em Deus.

O paladar pode se tornar, também, uma armadilha ao extrapolar o limite, pois o alimento e a bebida devem ser remédios para o corpo. $O$ olfato e a audição, do mesmo modo, podem se tornar entraves à felicidade. Para Agostinho, os prazeres do ouvido são mais dificeis de controlar, porque ele gosta muito de música, de modo que ele se esforça para não ultrapassar a medida.

A visão pode desviar também e é a última concupiscência da carne que o filósofo aborda. Ela desencaminha por causa das belezas que existem, das artes que são criadas, das roupas etc., o que pode levar a pessoa a seguir essas coisas maravilhosas e a esquecer do caminho da verdade. Não que as coisas do mundo sejam negativas em si, mas o problema é a desmedida, é desviar do que realmente é a felicidade. Há além dessas, outras tentações como a curiosidade, que se desvia para conhecer tudo através da ciência pela satisfação de conhecer e experimentar tudo. O orgulho é outra tentação. E para Agostinho, uma das suas maiores dificuldades são os louvores. Isso porque os louvores deveriam acompanhar a vida honesta e as boas ações e que ele deveria se alegrar pelo próximo e não por si mesmo com os louvores. Para ele, trata-se de uma grande tentação a estima dos outros. Mesmo o amor de si ou a autocomplacência exagerados são tentações.

Contudo, por mais que Agostinho ou qualquer outra pessoa se esforce para não exagerar, para não ultrapassar o limite, é inevitável que isso ocorra às vezes. Afinal, não deixamos de ser humanos e o mundo pode encantar de uma maneira que nos desvia da verdadeira felicidade, que somente podemos alcançar dentro da medida. Parece que quando o mundano está ocupando um espaço maior do que deveria em nossas vidas, o espiritual e/ou o autoconhecimento se afastam. Como se fosse possivel conviver com ambos somente em

23 SCHERER, 2006, p. 39. Ainda, vale destacar que "segundo Agostinho, a memória pode ser dividida em sensivel, armazenamento de dados advindos dos sentidos, e em intelectual, compreendendo noções gerais (verdades imutáveis e idênticas a todos, reveladas pelo Mestre Interior). A primeira é passiva, recebimento de imagens, e a segunda é ativa; é nela que o sujeito pode exercer atividade cognitiva, que tem como alicerce Deus. Conf.: SCHERER, 2006, p. 39

24 SANTOS, 2017, p. 154 
equilibrio. Não se trata de encontrar prazer apenas nas coisas exteriores, mas também nas coisas interiores. Isso porque as coisas externas devem ser um meio para alcançar o bem supremo que é Deus. Enfim, Agostinho afirma que toda a análise que realizou desde seus sentidos até alcançar a memória não seria possivel sem a ajuda de Deus.

É importante destacar que Agostinho não considera que terminou seu trabalho espiritual e pede a Deus que o ajude em suas fraquezas com relação a esse tema. Ou seja, o caminho para o conhecimento interior não tem fim. Porque esse trabalho interno não é fácil e rápido. É muito difícil passar pela vida sem que surjam questionamentos determinantes, tais como "Quem sou eu" e "Qual o propósito da minha vida?". Se as respostas serão procuradas e por quais vias serão, é já um segundo momento. Mas, é inevitável chegar a essas perguntas, porque o ser humano está na tensão entre sua natureza e o processo de se tornar humano.

Portanto, para Agostinho, a grande descoberta que fazemos na nossa interioridade é Deus, que não se manifesta de uma só vez para nós. E, por isso, o autoconhecimento nunca termina.

\section{Considerações finais}

Neste artigo vimos que a busca por entender a si mesmo, ou seja, procurar conhecer sua própria interioridade leva a descobrir Deus e a felicidade em nossa memória. Trata-se de um trabalho que se dirige a Deus como uma oração e à humanidade como testemunho do poder que a fé desempenhou na transformação de Agostinho.

Nas Confissões encontramos uma pessoa que se dedica a perscrutar os caminhos que percorreu na vida, sua conversão e sua fé de uma maneira que revela a confiança de que através da razão e da reflexão somos capazes de encontrar a Deus. A obra também revela um homem que não ignora a vida, suas fraquezas e sua força. Acima de tudo, é uma pessoa que não se considera como tendo vencido a luta interior, mas que sabe que estar vivo exige a busca constante do desenvolvimento pessoal.

Vimos que Agostinho empreende uma análise no presente sobre como encontrar Deus, pois não há dúvidas que ele ama Deus. Por isso, ele investiga o que ama em Deus percorrendo desde as coisas exteriores até sua interioridade. Esse método se revela muito produtivo, pois no mundo e no cosmos a única resposta que consegue encontrar é que seus habitantes são criaturas de Deus. Mas, não encontra Deus ele mesmo nas coisas. O resultado de embarcar para dentro de si é descobrir que Deus só pode ser encontrado em sua interioridade.

A análise revela também que o mais próximo de Deus em nós é a memória, porque ela guarda de alguma maneira a lembrança de Deus em nosso interior. Porém, somente através da razão começa essa busca e a possibilidade de descobrir que Deus sempre esteve em si. Agostinho também descobre que a verdadeira felicidade está em Deus. Em contrapartida, descobre também que as paixões desviam do caminho da felicidade, e que ele próprio cai, muitas vezes, nessa armadilha. Desse modo, somente Deus pode ajudá-lo a se tornar uma pessoa melhor.

Portanto, podemos compreender que Agostinho está revelando um processo também de autoconhecimento. Isso porque em todos os passos da investigação está o Eu em uma procura por se tornar um ser humano melhor, haja vista que ele identifica que sofre quedas espirituais causadas por fatores externos. Essas quedas e a vida desregrada afastam de Deus e afastam também de um conhecimento de si verdadeiro. Ao mesmo tempo, Agostinho mostra que não estamos destacados do mundo, e que, portanto, até quando buscamos Deus ou o caminho do conhecimento de si essa dimensão tem influência. Mas, as paixões não são somente negativas, porque enquanto elas não ultrapassam o limite podem nos ajudar no processo de autoconhecimento e desenvolvimento humano.

Entendemos, portanto, que no livro X Agostinho faz um estudo da tensão que define o ser humano: emergir da natureza, aspirar e procurar desenvolver-se constantemente. Essa tensão é o que motiva a busca pelo autoconhecimento. Isso exige tentativas, vamos procurar no mundo respostas. Muitas vezes, podemos encontrar caminhos que machucam, que fazem cair. Entretanto, 
as experiências impulsionam o desenvolvimento de si, de modo que um Eu verdadeiro pode surgir e encontrar a felicidade e a plenitude.

\section{Referências}

AGOSTINHO. Confissões. São Paulo: Paulus, 2016. Patristica.

FREDRIKSEN, Paula. Augustine on God and Memory. In: KATZ, STEVEN T.; ROSEN, ALAN; WIESEL, ELIE. Obliged by memory: literature, religion, ethics: a collection of essays honoring Elie Wiesel's seventieth birthday. Syracuse: Syracuse University Press, 2006. p. 131-138.

Disponivel em: http://www.bu.edu/religion/files/pdf/ Augustine-on-God-and-Memory.pdf. Acesso em: 2019.

MENDELSON, Michael. Saint Augustine. In: ZALTA, Edward N. (ed.). The Stanford Encyclopedia of Philosophy. California: Center for the Study of Language and Information (CSLI) - Stanford University, Winter 2018 Edition. Disponivel em: https://plato.stanford.edu/ archives/win2018/entries/augustine. Acesso em: 2019.

SANTOS, Renato Rodrigues dos. A interioridade e a busca da felicidade nas Confissões de Agostinho. Primeiros Escritos, São Paulo, n. 8, p. 133-161, 2017.

SCHERER, Fábio César. Memória e interioridade nas Confissões. São Leopoldo: Controvérsia, [S. I.], v. 2, n. 2 , p. 34-42, 2006. Disponivel em: http://www.revistas.unisinos.br/index.php/controversia/article/view/7067/0

Acesso em: 2019.

\section{Águeda Vieira Martinelli}

Mestra em Filosofia pela Pontificia Universidade Católica do Rio Grande do Sul (PUCRS), em Porto Alegre, RS, Brasil.

\section{Lilian Alencar da Silva}

Mestranda de Filosofia da Faculdade de Letras da Universidade de Lisboa (ULisboa), em Lisboa, Portugal.

\section{Endereço para correspondência}

Lilian Alencar da Silva/ Águeda Vieira Martinelli

Universidade de Lisboa

Alameda da Universidade, 1600-214

Lisboa, Portugal 